\title{
Collaborative Governance (Collaborative Study of Actors in Handling the Spread of Covid-19 in Indonesia)
}

\author{
Kus Indarto ${ }^{1^{*}}$; Susi Ratnawati ${ }^{2}$
}

Published online: 5 December 2021

\begin{abstract}
The purpose of this study is to analyze the collaboration of actors in handling the spread and the inhibiting factors in handling the spread of Covid-19 in Indonesia. Methodology: This study uses a qualitative approach, with a descriptive method. Data were obtained by studying literature, then analyzed by using interactive model data analysis. The areas studied are Gianyar Regency, Probolinggo City, and Padang City. The collaboration of actors in Gianyar Regency involves the Indonesian Youth National Committee and the Youth Officers Unit to Fight Covid-19. The collaboration of actors in Probolinggo City involves the local government, academics, and the community. Meanwhile, the collaboration actors in Padang City involve academics, the public, the private sector, local government, and the mass media. And all can be said to go well. The collaboration of actors in the areas studied has been going well, although the actors involved are different.
\end{abstract}

Keywords: Collaboration; Covid-19; Actor; Collaborative governance

\section{INTRODUCTION}

Since 2019, the world has been shocked by the Covid19 case which at that time appeared in Wuhan, China. We can see the news on television how tense the situation was in Wuhan at that time. The streets were deserted because no one dared to leave the house. Also, many Indonesian students who study there are stuck unable to return to Indonesia. Based on research conducted by Sukur, et al (2020), initially the Corona Virus appeared in the animal and seafood market in Wuhan City, China, in December 2019. The patient suffering from the Corona Virus was close to the animal and seafood market. At that time, we felt that Indonesia was safe because it was far from the city of Wuhan. We are still free to move quietly and do not feel there is a threat. But in its development, according to Sukur, et al (2020) on March 2, 2020, the Indonesian government officially announced that the Corona Virus had entered Indonesia. Two positive Indonesian citizens said that they had direct contact with Japanese citizens who were visiting Indonesia. On March 11, 2020, for the first time, there was a case of death caused by the virus. The

\footnotetext{
1*) Fakultas Ilmu Sosial dan Ilmu Politik Universitas

Mulawarman

${ }^{2}$ Fakultas Ilmu Sosial dan Ilmu Politik Universitas Bhayangkara

*) corresponding author
}

Kus Indarto

Fakultas Ilmu Sosial dan Ilmu Politik

Universitas Mulawarman Kalimantan Timur

Email: kusindarto@yahoo.com impact of the COVID-19 pandemic is dire, as it causes illness and death worldwide. For that, the government and semi-public institutions, and private organizations have struggled to overcome it. The Dutch government's response to Covid-19 shows that agility and adaptation can go hand in hand (Janssen and Van der Voort. 2020).

This means that it is not only the government that is trying to overcome the Covid-19 outbreak. Likewise in Indonesia. Non-governmental organizations play a role in handling the spread of COVID-19. Muis (2020) in Ryan (2020) said that the successful implementation of the Covid-19 handling policy cannot be separated from the role of various non-government actors.

\section{METHOD}

This research is using a qualitative approach. According to Moleong (2014, p.6), qualitative research is research that aims to understand the phenomena of what is experienced by research subjects, such as perceptions, motivations, actions, behaviors, and so on holistically / thoroughly by describing in the form of words and language, in a natural context and utilizing various natural methods. The method used is the descriptive method. The descriptive method according to Nazir (2003:54) is a method of researching a group of people, an object, a condition, a system of thought, or an event in the present. The purpose of descriptive research is to make a systematic, factual, and accurate description, picture, or painting of the facts, characteristics, and relationships between the phenomena being investigated. Furthermore, according to Bungin 
(2007, pp. 68-69), the qualitative descriptive format focuses on certain units of various phenomena. The data obtained are very in-depth. The source of data in this study is secondary data because this research is a literature study. A literature study according to Zed (2008) as quoted by Kartiningrum (2015) is a series of activities related to the methods of collecting library data, reading and taking notes, and processing research data. Then the data collected was analyzed using the Interactive Model Analysis according to Miles, Huberman, and Saldana (2014).

The location of this research is the handling of the spread of Covid-19 in 3 areas, namely Gianyar Regency, Bali Province; Probolinggo City, East Java Province; and Padang City, West Sumatra Province. The choice of location is due to the uniqueness of the area and also the innovations made by the area.

\section{RESULTS AND DISCUSSION}

Handling the spread of Covid-19 is a form of implementing government policies, both central and local governments. George Edward III (1980) as quoted by Dwidjowijoto (2006 h. 140-141) public implementation seeks to make public policies achieve their goals. Two steps must be taken in implementing public policies, first, directly implementing these public policies in the form of programs. Second, through policy formulation derived from public policy. Then, Wahab (2008:177) said that the function of implementing public policy is, first, to realize the goals or objectives of public policy as a result of activities from government activities. Second, create a policy achievement system.

The main actor in the implementation of public policy is the executive. However, in its development, other parties play a role in the implementation of public policies, namely first, the People's Representative Council/Regional People's Representative Council which makes programs using aspiration funds that are used to capture people's aspirations. Second, the private sector can cooperate with the government. Third, social organization according to Purwanto and Sulistyastuti (2012 pp125-128). However, in practice, the role of the House of Representatives/Regional House of Representatives is less visible.

Collaborative governance is governance that involves not only state institutions, but also non-state stakeholders in formal, consensus-oriented, and deliberative decisionmaking processes aimed at making or implementing public policies or managing public programs or assets (Ansell and Gash, 2003). 2008).

Thus the government does not take care of everything on its own. Collaboration with non-government actors is needed. Hirschhorn (2021) said the need for multi-actor, multi-sectoral collaboration, and various levels of government in the formulation of policies related to COVID-19. And of course, it is inseparable in its implementation.

This study will analyze the collaboration of actors in handling the spread of Covid-19 in three districts/cities. The first is Gianyar Regency. Research conducted by Arisanti and Suderana (2020) states that the Gianyar Regency Government collaborates with the Indonesian Youth National Committee (KNPI), which oversees and involves all youth in Gianyar. The collaboration focuses on efforts to handle the spread of Covid-19 by utilizing the Karina Application. The application can be downloaded on the Google Play Store. In the Karina Application, there are features, including self-checkup, general practitioner consultation (frog), psychological consultation/confession (curcol), a service call center connected to the Gianyar Regency Officer Unit, and the Screening Poli of the Sanjiwani Hospital Gianyar, as well as regular health reminders.

In addition, the Gianyar Regency Government is also collaborating with the Youth Officers Unit to Fight Covid19. The task force is based on menyama braya (Adhi, et al, 2019) in Airsanti and Suderana (2020). The values contained in the menyama braya are equality, brotherhood, social recognition that we are brothers and together in joy and sorrow. The concept encourages the community to create harmony and work together to develop the region. The local government in this case acts as a motivator so that Gianyar youth continue to grow and progress. Its activity is to spray disinfectant once a week in public places such as temples, village halls, banjar halls, people's houses, village borders, and also village markets.

Thus, it can be concluded that the Gianyar Regency Government is collaborating with the community (KNPI) and the Youth Task Force to Fight Covid-19 in dealing with the spread of Covid-19. Not involving other actors.

Second, Probolinggo City. Research conducted by Rahmawati, et al (2021) found that the Tangguh Semeru Benteng Village Program in the Mayangan Village/Subdistrict of Probolinggo City became the Responsibility Village Program in East Java (Susilo, 2020) in Rahmawati, et al (2021) found actors who played a role and collaborating are: local government, academics (Universities) and the community. The government's role is to implement a new life (new normal) and provide facilities. The form of activity is the supervision and assistance of the Tangguh Village Program. The role of academics (Universities) is to provide education to the community and take advantage of the potential of the village. The form of activity is to provide solutions and efforts to the government. Furthermore, the role of the community is to participate in helping academics in breaking the chain of the spread of Covid-19. The form of activities carried out by the community is to comply with health protocols and help each other between residents in need. They also make masks and face shields independently. The obstacle encountered is that there are still people who have low awareness of the importance of preventing the Covid-19 virus. Based on the research results, the collaboration carried out by the Probolinggo City Government has involved the government, academics (Universities), and the community.

Third, the Padang City Government. In handling the spread of Covid-19 in Padang City, the Padang City Government collaborates with the private sector, the community, academics, and the mass media. Their roles are as follows (Putera, et al, 2020): The Padang City Government formed Team V together with the Padang City Regional Leadership Coordination Forum (Forkopimda), Padang City Local Government Organizations (OPD) (which consisted of the Civil Service Police Unit|Satpol PP, Transportation Service, and Health Office) went to the field to Pasar Raya Padang to distribute 3600 masks and 250 leaflets regarding local regulations on adopting new habits, as quoted in www.covesia.com quoted by Putera, et al (2020). The role of the private sector is as follows: PT. Semen Padang distributed hand washing facilities. While Secret Clean PT. Victoria Care Indonesia assisted in the form of spraying disinfectant in public facilities such as places of worship and distributing hand sanitizer. The academics are involved in conducting the sample examination process, which is carried out by students and 
lecturers of the Faculty of Mathematics and Natural Sciences (FMIPA). Thus, the examination of samples no longer needs to be sent to the Health Research and Development Agency (Balitbangkes) of the Ministry of Health, so the results will be known faster (www.unand.ac.id). The mass media plays a role in providing socialization related to government policies to suppress Covid-19 cases. Finally, the role of the community can be seen from the involvement of "niniak mamak" and organda (land transportation organizations) in disseminating government policies related to new habits.

Actors involved and collaborating in handling the spread of Covid-19 in Padang City are the local government, private sector, academics, mass media, and also the community. Thus, all existing actors are already involved. The collaboration of actors in the three areas has been going well.

Muhyi, et.al (2017) as quoted by Yunas (2019) said that in collaboration there is a helix concept. Starting from the triple helix concept which consists of elements of the academic, business sector, and government. Then came the quadruple helix concept, which consisted of academics, the business sector, government, and mass media. And finally, the Penta helix concept emerged which consisted of academic, community, business sector governance, and mass media (ACBGM). Associated with the Penta helix concept, what has been fulfilled is the collaboration carried out by the Padang City Government.

Several countries have also collaborated in handling the spread of Covid-19. Even Jit, et, al., (2021) view the need for multilateral collaboration between countries to be successful in tackling emergencies related to infectious disease outbreaks. Overall, non-state actors and volunteers in North Jordan played an important role in reducing the impact of the Covid-19 outbreak (Khassawneh, et. 2020). The success of the Chinese government in dealing with the spread of Covid-19 is due to community social capital, namely the involvement and participation of civilians (liu, et, al., 2021); high preparedness, decisive and continuous action, diversion of resources for health care, and participation of the whole community in maintaining cleanliness (Olufadewa, et al., 2021). To increase awareness and involvement of young people in China in tackling Covid-19, the government is working with individual video uploaders to create and distribute entertaining videos containing information about Covid-19. The video is in the form of animation and music (He, et al., 2021). Regarding information about Covid-19, people in Xiamen China value the top-down information structure in China more than informal information from social media (Boas et al., 2021). However, American Non-Governmental Organizations use social media (Twitter) to respond, discuss and disseminate issues related to Covid-19 (Li, et. al, 2021). Meanwhile, South Korea is collaborating with the private sector to increase the number of PCR tests in Covid-19 cases (Park and Chung, 2021).

The inhibiting factors faced in handling the spread of Covid-19 are as follows:

In Gianyar Regency, the inhibiting factor in handling the spread of Covid-19 is the difficulty of coordination between the Covid-19 Poly and doctors at the Sanjiwani Hospital. This is due to time constraints and the large number of Covid-19 patients being treated at the Sanjiwani Hospital as one of the referral hospitals to treat Covid-19 patients (Arisanti and Suderana, 2020).

In the city of Probolinggo, the inhibiting factor in handling the spread of Covid-19 is the low public awareness of the importance of preventing Covid-19 (Rahmawati, et al, 2021). Meanwhile, the obstacles faced by the Padang City Government are the low public awareness of the dangers of Covid-19 and their low compliance with existing regulations (Putera, et al, 2020).

Thus it can be concluded that the obstacles faced in handling the spread of Covid-19 are the lack of coordination with other actors, the lack of public awareness of the dangers and prevention of covid, and lastly, the compliance of the public to comply with regulations.

\section{Lack of coordination between actors}

Coordination is a cooperation between agencies, agencies, units in carrying out certain tasks so that they can complement each other, help each other and complement each other (Westra, 2013) in Palit (2020). Palit (2020) found that the District Leadership Coordination Forum (FORKOPICAM) of North Minahasa Regency had been going well, to handle the spread of Covid-19. And it turns out that the coordination in Gianyar Regency has not gone well.

\section{Lack of public awareness of the dangers of Covid-19}

According to research conducted by Yatimah, et al (2020) public awareness of the dangers of Covid-19 is still minimal. Many people think that Covid-19 is not too dangerous and scary. A survey reported by Lapor COVID19 , in the Province of Jakarta, found that $16 \%$ believe that Indonesia is safe from the pandemic because Indonesia has a tropical climate. As many as $45 \%$ do not believe and the remaining $28 \%$ doubt. Even though as of July 31, 2020, there were 11,424 confirmed cases in DKI Jakarta. cases and 632 people died. Therefore, it is necessary to increase public awareness about preventing family-based Covid-19 transmission. Research conducted by Alahdal, Basingab, and Alotaibi (2020) shows that the level of public awareness in Riyadh, Saudi Arabia is moderate, therefore comprehensive public health education is needed, so that their awareness increases.

3. Lack of community compliance in complying with regulations.

Research conducted by Afrianti and Rahmiati. 2021 found that community compliance in complying with health protocols is influenced by: age, education, knowledge, attitudes, and motivation. Sobol, Blachnio, and Przepiorka (2020) say that women are more obedient to regulations related to Covid-19 than men.

\section{CONCLUSIONS AND RECOMMENDATIONS}

Efforts to deal with the spread of Covid-19 in Indonesia are carried out in collaboration. The actors involved in the collaboration are each different. Some have involved many actors, so they have fulfilled the Penta helix concept, namely the involvement of academics, community, business, government, and media. The problems faced in dealing with the spread of Covid-19 in Indonesia are lack of coordination, lack of public awareness, and lack of community compliance.

Recommendations from this study are the need to increase coordination between actors involved, increase public awareness and compliance with health protocols. 


\section{REFERENCES}

Afrianti, Novi; Rahmiati, Cut. 2021. Faktor-Faktor yang Mempengaruhi Kepatuhan Masyarakat terhadap Protokol Kesehatan Covid-19. Jurnal Ilmiah Permas: Jurnal Ilmiah STIKES Kendal, Vol.11, No.1:113-124.

Alahdal, Hadil; Basingab, Fatemah; and Alotaibi, Reem. 2020. An Analytical Study on the Awareness, Attitude and Practice during the COVID-19 Pandemic in Riyadh, Saudi Arabia. Journal of Infection and Public Health. Vol.13:14461452.

Ansell, Chris and Gash, Alison. 2008. Collaborative Governance in Theory and Practice. Journal of Public Administration Research and Theory. Vol.18:543-571.

Arisanti, Ni Made Dwi; Suderana, I Wayan. 2020. Penanganan Pandemi Covid-19: Kolaborasi Pemerintah Kabupaten Bersama KNPI Gianyar di Kabupaten Gianyar, Bali. Spirit Publik Jurnal Administrasi Publik. Vol.15, No.2.:87-96.

Boas, Ingrid; Chen, Chunci; Wiegel, Hanne; He, Guizhen. 2020. The Role of Social Media-Led and Governmental Information in China's Urban Disaster Risk Response: The Case of Xiamen. International Journal of Disaster Risk Reduction. Vol. 51:1-9.

Bungin, Burhan. 2007. Penelitian Kualitatif: Komunikasi, Ekonomi, Kebijakan Publik dan Ilmu Sosial lainnya. Jakarta: Kencana Prenada Media Group.

Dwidjowijoto, Riant Nugroho. 2006. Kebijakan Publik untuk Negara-Negara Berkembang: Model-Model Perumusan, Implementasi dan Evaluasi. Jakarta: Elex Media Komputindo.

He, Changyang; Liu, Huan; He, Lu; Lu, Tun; Li, Bo. 2021. More Collaboration, Less Seriousness: Investigating new strategies for promoting youth engagement in government-generated videos during the COVID-19 pandemic in China. Computer in Human Behavior. Vol.126:1-14.

Hirschhorn, Fabio. 2021. A Multi-Level Governance Response to the Covid-19 Crisis in Public Transport. Transport Policy. Vol.112:13-21.

Janssen, Marijn; Van der Voort, Haiko. 2020. Agile and Adaptive Governance in Crisis Response: Lessons from the COVID-19 Pandemic. International Journal of Information Management. Vol.55:1-7

Jit, Mark; Ananthakrishnan, Aparna; McKee, Martin; Wouters, Olivier J; Beutels, Philippe; Teerawattananon, Yot. 2021. Multi-Country Collaboration in Responding to Global Infectious Disease Threats: Lessons for Europe from the COVID-19 pandemic. The Lancet Regional Health - Europe. Vol. 9:1-8.

Kartiningrum, Eka Diah. 2015. Panduan Penyusunan Studi Literatur. Lembaga Penelitian dan Pengabdian Masyarakat Politeknik Kesehatan Majapahit Mojokerto.

Khassawneh, Hadi H; Alrabadi, Nasr; Al-Mistarehi, AbdelHameed; Obeidat, Nail; and Kheirallah, Khalid A. The role of non-state actors in combating COVID-19 spread in Northern Jordan. Annals of Medicine ang Surgery. Vol.60: 484-486.

Korea Selatan telah bermitra dengan swasta untuk meningkatkan jumlah test PCR dalam kasus Covid-19. Park, June and Chung, Eunbin. 2021. Learning from Past Pandemic Governance: Early Response and Public-Private Partnerships in Testing of COVID-19 in South Korea. World Development. Vol.137: 1-20.

Li, Yiqi; Shin, Jieun; Sun, JIngyi; Kim, Hye Min; Qu, Yan; Yang, Aimei. 2021. Organizational Sensemaking in Tough Times:
The Ecology of NGOs' COVID-19 Issue Discourse Communities on Social Media. Computers in Human Behavior. Vol. 122:1-15.

Miles, Matthew b; Huberman, A. Michael; Saldana, Johnny. 2014. Qualitative Data Analysis: A Methods Sourcebook. SAGE Publication.

Moleong, Lexy J. 2014. Metode Penelitian Kualitatif. Bandung: PT Remaja Rosdakarya.

Nazir, Moh. 2003. Metode Penelitian. Jakarta: Ghalia Indonesia.

Olufadewa, Isaac Iyinoluwa; Adesina, Miracle Ayomikun; Ekpo, Marlene Davis; Akinloye, Seyi John; Iyanda, Temiloluwa Ololade; Nwachukwu, Pamela; Kodzo, Lalit Dzifa. 2021. Lessons from the Coronavirus Disease 2019 (COVID-19) Pandemic Response in China, Italy, and the U.S.: A Guide for Africa and Low- and Middle-Income Countries. Global Health Journal. Vol.5:56-61.

Palit, Christan Leonard. 2020. Koordinasi Forum Komunikasi Pimpinan Kecamatan dalam Pencegahan Penyebaran Virus Corona (Covid-19) di Kecamatan Kalawat Kabupaten Minahasa Utara. Jurnal Politico. Vol.9, No.3:1-18.

Purwanto, Erwan Agus dan Sulistyastuti, Dyah Ratih. 2012. Implementasi Kebijakan Publik: Konsep dan Aplikasinya di Indonesia. Yogyakarta: Gava Media.

Putera, Roni Ekha. Valentina, Tengku Rika; Wialdi, Putri Febri; Audia, Nia. 2020. Collaborative Governance dalam Penanganan Penyebaran Kasus Corona Virus Disease-19 di Kota Padang. Prosiding Konferensi Nasional Ilmu Administrasi 4.0. 133-137.

Rahmawati, Yusrin; Anugrah, Farah FAdillah; hati, ERva Mutiara; Roziqin, Ali. 2021. KampungTangguh:Wujud Kolaborasi antar-Stakeholderdalam Merespons Pandemi COVID-19. Journal of Social Development Studies, Vol.2, Issue 1:39-51.

Ryan, Jacko. 2020. Peranan Jaringan Aktor dalam Kebijakan Penanganan Covid-19 di Indonesia. Journal Publicuho. Vol.3, No.3:491-509.

Sobol, Małgorzata; Blachnio, Agata; Przepiorka, Aneta. 2020. Time of Pandemic: Temporal Perspectives Related to Compliance with Public Health Regulations Concerning the COVID-19 Pandemic. Social Science \& Medicine. Vol. 265:1-5).

Sukur, Moch. Halim; Kurniadi, Bayu; Haris; Faradillahisari, Ray;.2020. Penanganan Pelayanan Kesehatan Di Masa Pandemi Covid-19 dalam Perspektif Hukum Kesehatan. Journal Inicio Legis Vol. 1, No. 1:1-17.

Wahab, Solichin Abdul. 2008. Pengantar Analisis Kebijakan Publik. Malang: UMM Press.

Yatimah, Durotul; Kustandi, Cecep; Maulidina, Azmira; Irnawan, Fernanda; Andinnari, Shaffiya. 2020. Peningkatan Kesadaran Masyarakat tentang Pencegahan Covid-19 Berbasis Keluarga dengan Memanfaatkan Motion Grafis di Jakarta Timur. Jurnal Karya Abadi, Vol.4, No.1:246-255.

Yunas, Novy Setia. 2019. Implementasi Konsep Penta Helix dalam Pengembangan Potensi Desa melalui Model Lumbung Ekonomi Desa di Provinsi Jawa Timur. Jurnal Matra Pembaruan 3 (1):37-46. 